\title{
MEMAHAMI POLA KOMUNIKASI KELOMPOK ANTAR ANGGOTA KOMUNITAS PUNK DI KOTA SEMARANG
}

\author{
Aditya Oktendy Saputra \\ (toysfactoryrunner@yahoo.com) \\ (Alumni Program Studi Ilmu Komunikasi Universitas Semarang)
}

\begin{abstract}
Communications between members of the community in Semarang City Punk and How to use the Punk communication media in the city of Semarang by its members, in order to maintain harmony among communities. The population in this study were community members who live in areas Punk Genuk in the city of Semarang. While as many as 5 samples taken by the informant in-depth interview technique (depthinterview). The pattern of communication is known that a person's personality represents a real community members. the Punk community to gain acceptance from other members, an individual is forced to follow the pattern of communication other community members, so that communication patterns can be understood by everyone or is universal. And by using various social networking Punk community members can communicate with their comrades from other communities to get out of town, in order to maintain the relationship, strengthen kinship and closeness even though they do not have long to meet.
\end{abstract}

Keywords: Group communication, Punk community, The pattern of communication. kaum buruh yang mempunyai pandangan yang sama terhadap tindakan

\section{PENDAHULUAN}

Pada awal kemunculannya, Punk merupakan sebuah gerakan perlawanan yang dilakukan oleh sekelompok buruh di Inggris yang tidak puas dengan sistem sosial yang berlaku pada saat itu yang mengelompokkan masyarakat menjadi dua golongan, yaitu kaum pengusaha (pemilik modal) dan kaum pekerja. Ketidakpuasan para buruh terutama diakibatkan oleh perlakuan masyarakat kelas pengusaha terhadap kelas pekerja. Kesenjangan sosial yang terjadi dan eksploitasi yang dilakukan kaum pengusaha terhadap kaum buruh menimbulkan perasaan senasib diantara para buruh dan kemudian melahirkan sebuah pergerakan yang menentang sistem kapitalisme. Pergerakan tersebut kemudian membentuk sebuah komunitas yang anggotanya terdiri atas

sewenang-wenang para pemilik modal. Dengan menganut prinsip Do $I t$ Yourself dan Equality, gerakan resistensi radikal yang kemudian menjadi budaya penentang tersebut dikenal sebagai Punk (www.punkpages.cjb.net / 10 Mei 2011 23.00 WIB).

Pergerakan Punk di Indonesia telah masuk sejak tahun 1970-an tetapi baru benar-benar meledak pada tahun 1990an. Hal ini disebabkan oleh ekspos media massa terhadap komunitas Punk yang baru terjadi pada pertengahan 1990-an dan kemudian mengubah pergerakan resistensi radikal menjadi sebuah budaya trend global dari kapitalisme.

THE MESSENGER, Volume IV, Nomor 1, Edisi Januari 2012 
Disebut demikian karena, sekarang anak-anak muda yang mengikuti pergerakan Punk hanya sebatas penampilan luarnya saja dan tidak tahu apapun mengenai Punk itu sendiri kecuali anarkisme yang sering identik dengan komunitas Punk. Padahal, anarki menurut Punk adalah anarki dalam cara berpikir dan bagaimana Punk bisa melakukan pemberontakan dengan cara sendiri.

Menurut Yasraf Amir Piliang dalam Beyond the Barbed Wire (2005) punk lahir tanpa subtansi sejak awal. Ia tidak lahir dari sebuah bentuk resistensi, melainkan dari sebuah kerinduan akan sebuah bentuk representasi baru saat ada hal lama yang dapat merepresentasikan diri kita lagi.

Maka tidak mengherankan apabila hal-hal yang subtansial baru hadir bertahun-tahun setelah punk dikenal secara musikal dan dalam konteks fashionnya.(deathlock.wordpress.com/2 007/11/26/kekuatan-opresif-kelompokmayoritas/. 10 Mei 2011 pukul 23.30 WIB).

Terkait dengan sejarah pergerakan Punk, anggota komunitas Punk menuangkan ideologi pergerakan mereka melalui simbol-simbol yang sampai sekarang tetap melekat dan menjadi identitas dari komunitas Punk di seluruh pelosok wilayah. Simbolsimbol tersebut dituangkan melalui gaya hidup, cara berpakaian dan jenis musik yang dimainkan oleh anak-anak Punk.

Cara berpakaian anak-anak Punk yang cenderung lusuh dan terlihat menyeramkan karena berbagai macam aksesori yang tidak biasa digunakan oleh anak-anak muda pada umumnya mempunyai arti khusus dan berhubungan erat dengan sejarah awal pergerakan Punk.

Bukan karena keinginan untuk tampil beda dan untuk menarik perhatian saja. Simbol-simbol tersebut antara lain sepatu boots Doc Mart yang melambangkan kaum buruh itu sendiri sebagai penggagas pergerakan Punk, sedangkan celana jins ketat yang panjangnya di atas mata kaki dengan jas dan dasi yang sering dikenakan oleh para Rude Boy (komunitas Ska/Tutons) dimaksudkan untuk menyindir kaum Borjouis. Gaya rambut Mohawk, safety pin, kalung anjing dan gelang spike melambangkan perlawanan terhadap kemapanan dan modernisasi.

Komunitas Punk lahir di jalanan dan anggota dari komunitas tersebut juga merupakan orang-orang jalanan, maka tempat berkumpul anak-anak Punk adalah di jalan. Tempat yang biasa digunakan untuk berkumpul (dalam istilah komunitas Punk disebut sebagai nye-treet, diambil dari kata street yang berarti jalan) adalah di perempatan jalan dan sekitar pinggiran pusat keramaian, dimana mereka juga mencari uang dari mengamen.

Di Semarang, perempatanperempatan jalan yang sering digunakan untuk nye-treet antara lain di lampu merah Genuk Sayung, ruko pertokoan dekat masjid Panut lampu merah Palebon Pedurungan, Depan McD Mall Ciputra (Total Spike/TS), serta Taman Singosari yang biasa disebut Tamsing depan Wonderia. Berdasarkan lokasi nye-treet tersebut maka muncul istilah Punk Cah Genuk, Punk Cah Tamsing, Punk Cah Palebon atau pun Punk Cah TS/Total Spike.

Penamaan komunitas Punk di masing-masing daerah tersebut bukan dimaksudkan sebagai pembatas atau tindakan pengkotak-kotakan komunitas sebab pada dasarnya anak-anak Punk yang ada di scene Semarang adalah orang-orang yang sama apa pun sebutannya dan menjadi satu komunitas. Pemberian nama itu hanya untuk memudahkan dalam mengidentifikasi 
lokasi yang menjadi tempat nye-treet anak-anak Punk.

Dalam kehidupannya anak-anak Punk yang mempunyai kegiatan nyetreet tersebut sering dikenal dengan istilah 'Street Punk'. Dalam pergerakan Punk terdapat berbagai macam jenis Punk dengan aliran musik yang berbeda. Namun, inti dari pergerakan Punk itu sendiri apa pun jenis alirannya adalah sama yaitu 'Do It Yourself'. Idealisme tersebut seolah menjadi sebuah harga mati bila ingin ikut ke dalam komunitas Punk dan masuk menjadi anggota komunitas Punk. Dari idealisme tersebut, para anggota komunitas Punk mewujudkannya melalui fashion, life style dan terutama melalui musik.

Punk dan musik adalah satu kesatuan. Karena kebanyakan anakanak Punk adalah musisi maka gerakan yang paling dominan adalah melalui musik, yaitu dengan mengusung genre musik indie label atau underground. Musik dengan irama bertempo cepat dan suara gitar berdistorsi kasar serta syair lagu yang penuh dengan kritik sosial merupakan ciri dari musik dalam komunitas Punk.

Musik menjadi media komunikasi bagi komunitas Punk dalam menyampaikan protes mereka terhadap tatanan sosial masyarakat. Selain itu, musik dengan syair-syair lagu yang sarat dengan kritik sosial politik dapat menjadi sarana pendidikan politik yang ampuh bagi anggota komunitas Punk. Tetapi, lirik lagu yang dimainkan oleh band-band Punk tidak hanya bertema sosial politik saja, ada juga yang mengangkat tema mengenai kehidupan sehari-hari anak-anak Punk.

Bentuk komunikasi yang terjadi di dalam komunitas Punk di Semarang adalah melalui newsletter, pamflet underground, event musik serta kegiatan nye-treet yang biasanya memakan waktu hingga berjam-jam dan dilakukan setiap hari terutama pada Sabtu malam.

Kegiatan nye-treet yang sering dilakukan oleh anak-anak Punk menjadi sarana paling efektif untuk berdiskusi, saling bertukar informasi ataupun sebagai sarana sosialisasi pergerakan Punk untuk para Poser (orang yang tertarik dengan pergerakan Punk namun bukan seorang anggota Punk) dan sarana publikasi acara musik yang akan diadakan oleh komunitas Punk di daerah tertentu.

Pada saat nye-treet tersebut, anakanak Punk biasanya berdiskusi seputar isu-isu yang terjadi di masyarakat maupun di dalam komunitasnya sendiri dan saling bertukar informasi berupa news letter, zine, kaset, literatur, majalah maupun pamflet acara musik terbitan underground. Pertukaran informasi yang terjadi tersebut biasanya menjadi sarana sosialisasi pergerakan Punk bagi anggota komunitas Punk yang baru bergabung dan ingin mengetahui lebih dalam mengenai Punk dan idealismenya. Berawal dari kegiatan nye-treet tersebut sering kali muncul diskusi mengenai penyelenggaraan event-event musik Punk. Sampai saat ini, event musik yang berhasil diselenggarakan oleh komunitas Punk Semarang, antara lain "Java Disorder", "Semarang Bernyanyi Bersama" (SBB), "Ayo Seduluran" (yang bekerja sama dengan komunitas Punk dari Ambarawa), dsb.

Proses pelaksanaan event-event musik atau biasa disebut "Gigs" tersebut biasanya bermula dari gagasan beberapa orang anak Punk yang sedang nye-treet kemudian dikembangkan menjadi sebuah rapat besar yang melibatkan anggota komunitas Punk di Semarang melalui perwakilan dari masing-masing wilayah (Punk Cah genuk, Punk Cah Tamsing, Punk TS, 
dsb). Setelah melalui beberapa kali pertemuan dan tercapai kesepakatan bersama, masing-masing wilayah biasanya akan membantu panitia dengan memberikan donasi berupa uang hasil kolektifan dari masing-masing scene maupun alat-alat musik.

Kegiatan-kegiatan seperti itulah yang memperkuat solidaritas dan menjadi media komunikasi bagi anggota komunitas Punk Kota Semarang. Namun, seiring dengan perkembangan jenis media serta kemajuan di bidang teknologi, anak-anak Punk Semarang saling berinteraksi dan berkomunikasi dengan anggota komunitas Punk di kota lainnya melalui internet.

Kegiatan komunikasi yang dilakukan antara lain dengan saling mengirim $e$ mail, diskusi melalui mailing list ataupun mengakses situs dan zine underground yang dibuat oleh komunitas Punk di wilayah tertentu seperti. $\quad$ www.punkpages.cjb.net, www.papakermadistro.cjb.net, www.fastnbulbous.com, www.semarangonfire.com atau www.geocities.com/innergarden_zine.

Melalui internet, interaksi anggota komunitas Punk baik lokal Kota Semarang, Nasional, maupun internasional semakin terjalin dengan baik dan menambah pengetahuan bagi masing-masing anggota komunitas.

Penelitian ini hanya akan meneliti pola komunikasi yang terjadi diantara anggota komunitas Punk di Kota Semarang, bukan pola komunikasi dengan orang awam yang bukan dari dalam komunitas bahkan di luar komunitas.

Berdasarkan gagasan-gagasan pada latar belakang di atas, maka poin-poin permasalahan yang ingin diteliti adalah:

1. Bagaimana pola komunikasi yang dilakukan antara anggota komunitas Punk di Kota Semarang?
2. Bagaimana pemanfaatan media komunikasi Punk di Kota Semarang oleh anggotanya, dalam rangka menjaga keharmonisan antar komunitas?

\section{TINJAUAN PUSTAKA}

Teori pertama yang digunakan dalam penelitian ini adalah teori fungsional, yaitu dalam komunikasi kelompok memandang proses sebagai sebuah instrumen dimana kelompok membuat keputusan, menekankan hubungan antar kualitas komunikasi dan hasil dari kelompok (Barker, 1994 ; 19-43). Komunikasi melakukan sejumlah hal atau fungsi dengan banyak cara untuk menentukan hasil kelompok. Ini adalah sarana untuk berbagi informasi, cara anggota kelompok menyelidiki dan mengidentifikasi kerusakan dalam pikiran, dan sebuah cara persuasi (Simon, 1976; 344). Walaupun metode penelitian digunakan untuk mempelajari fungsi kelompok mirip dengan semua yang dilihat dalam tradisi psikologi sosial, kita telah meletakannya disini, dalam sosial budaya, karena memiliki hubungan yang kuat dengan tradisi sosial budaya yang lebih besar yang melihat bagaimana kelompok bekerja.

Pendekatan fungsional telah sangat berpengaruh dengan pengajaran prakmatik dalam kelompok diskusi kecil. Ini berdasarkan dari penelitian kinerja oleh filsuf John Dewey, sejak mempublikasikan "How We Think" pada tahun 1910, yang sangat berpengaruh terhadap pemikiran prakmatik abad ke-20. Versi Dewey dalam proses pemecahan masalah memiliki enam langkah mengungkapkan kesulitan; menjelaskan permasalahan; penganalisis masalah; (4) menyarankan solusi; (5) membandingkan alternatif dan menguji mereka dengan tujuan dan kriteria yang berlawanan; dan (6) 
mengamalkan solusi yang terbaik. Teori dari tradisi fungsional menyebut cara yang mempengaruhi tiap-tiap elemen ini (Little John, 2009: 344).

Dalam media komunitas terdapat peranan dari orang lain yang mempengaruhi pola pikir kita, dan itu berada di dalam kelompok dimana kita juga menjadi anggotanya, besar atau kecil, formal atau informal. Kelompok orang ini bisa mempunyai dampak yang besar pada cara kita menerima pesan. Keanggotaan kelompok dapat menciptakan sikap prasangka yang sulit diubah. Berikut ini adalah jenis-jenis kelompok yang paling penting. Kelompok Primer (primary group) adalah sebuah kelompok (dua orang atau lebih) yang melibatkan perkumpulan yang anggotanya bertemu langsung dengan akrab selama jangka waktu yang lama. Kelompok Acuan (refference group) adalah sebuah kelompok yang dikenali dan digunakan sebagai standar acuan namun tidak mesti dimiliki. Kelompok Kasual (casual group) adalah sekelompok orang yang terbentuk satu kali saja dan anggota kelompok tersebut tidak saling mengenali satu sama lainya sebelum mereka berkumpul. (Severin, 1990: 219-220).

Dalam komunitas Punk terdapat juga media yang mereka gunakan untuk berkomunikasi antara anggota satu dengan yang lain baik itu dalam satu komunitas maupun beda komunitas dengan tempat yang berbeda pula. Mereka biasanya menggunakan media informasi berupa news letter, zine, kaset, literatur, majalah maupun pamflet acara musik terbitan underground. Pertukaran informasi yang terjadi tersebut biasanya menjadi sarana sosialisasi pergerakan Punk bagi anggota komunitas Punk yang baru bergabung dan ingin mengetahui lebih dalam mengenai Punk dan idealismenya. bahkan mereka juga menggunakan media yang lebih moderen lagi seperti internet. Meskipun mereka banyak hidup di jalanan, mereka juga mempunyai akun Facebook bahkan hingga MySpace. Dengan menggunakan media tersebut lah para anggota komunitas Punk dapat berkomunikasi dan berbagi pesan atau saling menyapa dengan kawan-kawan mereka dari komunitas lain hingga keluar daerah bahkan luar pulau.

Media massa jelas terkait dengan kultur karena melalui media massa itulah orang-orang kreatif punya tempat yang cepat. Meski media punya potensi menyebarluaskan karya kreatif terbaik dari pikiran dan jiwa manusia, beberapa krirtikus mengatakan media sangat obsesif terhadap subjek-subjek trendi, yang kadang menggelikan. Para kritikus ini juga menemukan kesalahan serius dalam perhatian media terhadap kultur pop, karena kultur pop dianggap tidak mengandung isi yang signifikan. (Marshall Mcluhan, 1998: 506).

Teori pemikiran kelompok adalah sebuah hasil langsung terhadap kepaduan kelompok yang telah dibahas beberapa bagian oleh Kurt Lewin pada tahun 1930-an dan semenjak dilihat sebuah variabel penting dalam keefektifan kelompok. Kepaduan (cohesiveness) adalah tingkatan minat ganda diantara anggota kelompok. Dalam sebuah kelompok yang sangat padu, sebuah identifikasi ganda menjaga sebuah kelompok bersamasama. Dan juga kepaduan adalah sebuah hasil dari tingkatan yang semua anggota merasa bahwa tujuan mereka dapat tercapai dalam golongan. Ini tidak membutuhkan anggota yang memiliki sikap yang sama, namun anggota yang menunjukan sebuah tingkatan saling ketergantungan, bersandar pada satu sama lain untuk meraih tujuan yang diingini. Semakin kelompok padu, 
tekanan akan lebih mendesak anggota untuk menjaga kepaduan tersebut (Little John, 2009: 346).

Demikian penting kedudukan teori khususnya dalam suatu kegiatan penelitian, sehingga hampir tidak ada sesuatu yang tidak berangkat dari teori dengan satu atau beberapa fungsinya. Kemudian sebuah teori diarahkan untuk menjawab pertanyaan mengapa (bagaimana) timbul regularitas alam, dengan demikian teori harus memuat pertanyaan tentang mekanisme tertentu, serta hubungan antar variabel dalam fenomena yang diselidiki (Kaplan dan Manners, 2002: 123). Dalam penelitian kualitatif teori yang dikembangkan dimulai dilapangan studi dari data yang terpisah-pisah dan atas bukti-bukti yang terkumpul serta saling berkaitan. Penekanannya pada proses analisis induktif, sehingga penelitian yang demikian juga disebut sebagai "empirico inductive researh" (Sutopo, 2002: 39)

Komunikasi merupakan proses dimana suatu ide dialihkan dari sumber kepada satu penerima atau lebih dengan maksud mengubah perilaku. Dalam komunikasi ada sebuah proses pengoperan (pemrosesan) ide, gagasan, lambang, dan di dalam proses itu melibatkan orang lain. Harold D Lasswell menyatakan bahwa cara yang baik untuk menggambarkan komunikasi adalah dengan menjawab siapa menyatakan apa dengan saluran apa kepada siapa dan efeknya bagaimana. (Marhaeni Fajar, 2009: 32).

Menurut Hafied Changara (2000), terjadinya proses komunikasi ini karena adanya seseorang yang menginterpresentasikan sebuah objek dan pikirannya. Objek tersebut bisa berbentuk benda, informasi, alam, peristiwa, pengalaman, atau fakta yang dianggap berarti bagi manusia. Berbagai objek tersebut bisa terjadi pada diri sendiri dan diluar diri sendiri. Untuk selanjutnya objek itu diberi arti, diinterpretasikan berdasarkan pengalaman yang berpengaruh pada sikap dan perilaku seseorang. Oleh karena itu masing-masing orang berbeda dalam memberi interpretasi dan kepekaan diri, maka masingmasing orang berbeda pula dalam proses penentuan tindakan apa yang akan dilakukan.

Apabila diaplikasikan secara benar komunikasi akan mencegah dan menghilangkan konflik antarpribadi, antarkelompok, antarsuku, antarbangsa, dan antarras. Hakikat komunikasi adalah proses penyampaian pesan dengan dengan menggunakan bahasa sebagai penyalurnya. Komunikasi berlangsung dalam berbagai tingkat kesengajaan untuk meraih tujuan dari komunikasi sendiri. Tujuan tersebut antara lain, mengubah sikap, opini, perilaku, dan mengubah masyarakat. Dimana dari tujuan tersebut dapat dilihat bahwa komunikasi tersebut memang berlangsung dari kesengajaan di mana fungsi dari komunikasi itu sendiri, menginformasikan, mendidik, menghibur, dan mempengaruhi (Marhaeni Fajar, 2009: 38).

Guna mencapai kunci sukses suatu komunikasi perlu diperhatikan prinsip komunikasi yang efektif yakni, jenis publik yang menjadi sasaran, susunan pesan yang tepat dan mudah dipahami, serta saluran apa yang sesuai dengan sifat publik yang dituju (Marhaeni Fajar, 2009: 56).

Dalam kegiatan berkomunikasi efek atau perubahan diharapkan terjadi bukan saja pada seseorang, melainkan kepada orang banyak atau masyarakat. Khalayak penerima yang terdiri dari banyak orang menjadi sasaran pesan komunikasi yang diharapkan efektivitasnya. 
Masing-masing orang mempunyai perbedaan dalam mengaktualisasikan komunikasi. Oleh karena itu, dalam komunikasi dikenal dengan pola-pola tertentu sebagai manifestasi perilaku manusia dalam berkomunikasi. Pola komunikasi dibagi menjadi empat, yakni komunikasi antarpribadi, komunikasi kelompok kecil, komunikasi publik dan komunikasi massa.

Komunikasi kelompok mempunyai tujuan dan organisasi (meskipun tidak selalu formal) dan melibatkan interaksi diantara anggota-anggotanya. Jadi, ada dua tanda kelompok secara psikologis yaitu :

a. Anggota-anggota kelompok merasa terikat dengan kelompok (ada sense of belonging, yang tidak dimiliki orang yang bukan anggota).

b. Nasib anggota-anggota saling bergantung, sehingga hasil setiap orang terkait dalam cara tertentu dengan hasil yang lain.

Ada empat faktor situasional yang mempengaruhi efektifitas komunikasi kelompok adalah, ukuran kelompok, jaringan komunikasi, kohesi kelompok, kepemimpinan. Seperti halnya tindakan komunikasi, peranan yang dimainkan oleh anggota kelompok dapat membantu penyelesaian tugas kelompok, memelihara hubungan emosional yang baik, atau hanya mementingkan kepentingan individu saja (Riswandi, 2008: 120-128).

Komunikasi merupakan alat utama dalam kehidupan sosial manusia. Dewasa ini komunikasi tidak hanya menyangkut satu orang ke orang lainnya melainkan melibatkan khalayak yang banyak dan di berbagai daerah yang berbeda yang kemudian disebut sebagai komunikasi massa.

Dalam komunitas Punk terdapat juga media-media yang mereka gunakan untuk berkomunikasi antara anggota satu dengan yang lain baik itu dalam satu komunitas maupun beda komunitas dengan tempat yang berbeda pula. Mereka biasanya menggunakan media yang moderen seperti internet. Meskipun mereka banyak hidup di jalanan, mereka juga mempunyai akun Facebook bahkan hingga MySpace. Dengan menggunakan media tersebut lah para anggota komunitas Punk dapat berkomunikasi dan berbagi pesan atau saling menyapa dengan kawan-kawan mereka dari komunitas lain hingga keluar daerah bahkan luar pulau.

Menurut Dennis McQuail ciri utama komunikasi massa adalah sumber komunikasi massa bukanlah satu orang melainkan suatu organisasi formal, dan "sang pengirim-nya" seringkali merupakan komunikatornya. Pesannya tidak unik dan beraneka ragam, serta dapat diperkirakan. Hubungan antara pengirim dan penerima bersifat satu arah dan jarang sekali bersifat interaktif. Hubungan tersebut bersifat impersonal, bahkan mungkin seringkali bersifat non-moral dan kalkulatif, dalam pengertian bahwa sang pengirim biasanya tidak bertanggungjawab atas konsekuensi yang terjadi pada para individu dan pesan yang diperjual belikan dengan uang atau ditukar dengan perhatian tertentu (McQuail, 1987: 34-35).

Ada beberapa sifat yang melekat dalam komunikasi masa dan sekaligus membedakannya dengan bentuk komunikasi yang lainnya. Sifat yang dimaksud menyangkut sifat komunikator, sifat pesan, sifat media massa, sifat komunikan, sifat efek, dan sifat umpan balik (Marhaeni Fajar, 2009: 224).

\section{METODE PENELITIAN}

1. Bentuk dan Strategi Penelitian

Bentuk dan strategi penelitian yang berjudul Memahami Pola Komunikasi Kelompok Antar Anggota Komunitas 
Punk Di Kota Semarang ini merupakan penelitian yang menggunakan metode penelitian deskriptif kualitatif dengan paradigma interpretive. Menurut $\mathrm{F}$. L. Whitney, penelitian deskriptif dipakai untuk mencari data melalui interprestasi secara tepat (Nazir, 2003: 54). Peneliti berusaha mengkaji dan memberikan penjelasan teoritik tentang bagaimana pola komunikasi yang dilakukan oleh anggota dalam komunitas Punk di Kota Semarang. Hingga dapat memberikan deskripsi secara untuh mengenai pengalaman subyek tersebut tentang bagaimana mereka berkomunikasi untuk memecahkan masalah dalam rangka menjaga keharmonisan komunitas.

Aspek yang ditekankan dalam perspektif interpretive ialah subjektivisme atau keunggulan pengalaman individu. Teori-teori interpretive menggambarkan proses pikiran aktif untuk mengingat kembali pengalaman individu atas kejadian apapun yang dialaminya (Littlejohn, 1999: 15).

2. Data dan sumber data

Dalam penelitian kualitatif, pengumpulan data dilakukan pada natural setting atau kondisi yang alamiah, sumber primer dan teknik pengumpulan data lebih banyak pada observasi berperan serta (participant observation), wawancara mendalam (indepth interviev) dan dokumentasi. Catherine Marshall, Gretchen B. Rossman, menyatakan bahwa "the fundamental methods relied on by qualitative researchrs for gathering information are, participation in the setting direct observation, in-depth interviewing, document review" (Sugiyono, 2008: 225).

a. Data primer

Merupakan data utama yang diperoleh langsung dari key informant yang sekaligus merupakan subyek penelitian ini melalui wawancara mendalam (indepth interview) yang dipilih secara purposive dengan menggunakan interview guide sebagai pedoman wawancara. Populasi sampel dalam penelitian ini adalah komunitas Punk Cah Genuk, dengan karakteristik khas komunitas sampel sebagai berikut:

1) Komunitas Punk di daerah Genuk yang merupakan salah satu komunitas Punk terbesar di kota Semarang.

2) Komunitas Punk Cah Genuk merupakan komunitas yang paling sering berinteraksi dengan komunitas lain dari luar kota. Karena lokasi mereka berkumpul berada di sekitar lampu merah Genuk, yang merupakan daerah strategis dan menjadi jalur lalu lintas pantura. maka dari itulah seringkali dijadikan ajang berkumpulnya anggota komunitas Punk dari luar kota untuk singgah dan beristirahat, sebelum mereka melanjutkan perjalanan lagi dengan menumpang truk bak terbuka atau mereka biasa menyebutnya ngeplat.

3) Aktivitas komunikasi yang sering dilakukan, ditandai dengan:

- Berkomunikasi secara lisan jika ada teman dari komunitas lain di luar kota yang kebetulan singgah dan membagikan selebaran pamflet acara gigs bahkan menggunakan internet, misal melalui akun-akun Facebook dan Twitter yang mereka miliki untuk menghubungi dan memberi kabar demi menjaga silaturahmi dan komunikasi dengan anggota komunitas lain di luar kota.

- Mempunyai akun Facebook dan Myspace untuk berkomunikasi melaui dunia maya dengan membagikan pamflet 
elektronik kepada teman-teman komunitas lain di luar kota, untuk mengabari seputar acara gigs Punk yang akan diadakan di dalam kota Semarang maupun luar kota.

- Melakukan aktivitas
chatting dengan anggota
komunitas lain untuk sekedar
saling menyapa maupun bertukar
pikiran dalam penyelesaian
sebuah permasalahan atau
membahas seputar isu yang
berkembang.

\section{b. Data sekunder}

Merupakan data terkumpul dari sumber-sumber terkait dan sumbersumber lain yang memiliki relevansi dengan masalah yang diteliti seperti: buku, jurnal penelitian, artikel, surat kabar dan internet. Data sekunder tersebut dimanfaatkan untuk interprestasi, pengkajian, penelaahan, analisis masalah penelitian dan juga untuk pengembangan kerangka pemikiran.

\section{Teknik Sampling}

Berkenaan dengan tujuan penelitian di atas, maka dalam prosedur sampling yang terpenting adalah bagaimana menentukan informan kunci (key informant) atau situasi sosial tertentu yang sarat informasi sesuai dengan fokus penelitian (Bungin, 2005: 53). Populasi adalah keseluruhan subjek penelitian (Arikunto, 1998: 115). Populasi penelitian ini adalah anggota komunitas Punk cah genuk yang merupakan komunitas terbesar di Kota Semarang berjumlah kurang lebih 150 anggota.

Sampel adalah sebagian atau wakil populasi yang diteliti (Arikunto, 2006: 131). Untuk memilih sampel (dalam hal ini informasi kunci atau situasi sosial) lebih tepat dilakukan secara sengaja (purposive sampling). Teknik ini mendasarkan pada ciri-ciri atau sifatsifat tertentu informan yang mempunyai sangkut paut erat dengan ciri-ciri atau sifat-sifat yang ada dalam subjek penelitian. Jadi ciri-ciri atau sifat-sifat spesifik yang ada dalam subyek penelitian, dijadikan kunci untuk pengambilan jumlah informan (Achmadi, 2002: 116). Berdasarkan pada pertimbangan teoritik tersebut, maka penelitian kualitatif ini tidak dipersoalkan jumlah informannya. Dalam hal ini, jumlah informan bisa sedikit tetapi juga bisa banyak, tergantung sampai tercapainya tujuan penelitian. Kriteria dalam memilih orang-orang tertentu dari populasi sasaran dengan kriteria tertentu untuk dijadikan sampel dalam penelitian ini yaitu:

Anggota komunitas Punk yang berdomisili di daerah Genuk dan selalu eksis dalam berbagai acara komunitas di Kota Semarang.

Aktif menjadi anggota komunitas Punk ditandai dengan:

- Mempunyai banyak teman komunitas dan saling mengenal dengan anggota komunitas yang lain.

- Dalam kesehariannya selalu berkumpul dan berinteraksi dengan seluruh anggota komunitas yang ada.

- Melakukan aktifitas sehari-hari selalu berdampingan dan bersamasama dengan anggota lain di dalam komunitas.

Sesuai dengan kriteria diatas, maka peneliti menentukan sampel sebanyak 5 (lima) orang yang diambil dari anggota komunitas Punk cah Genuk yang sesuai dengan kriteria sampel untuk mewakili penelitian ini.

4. Teknik pengumpulan data 
Data penelitian ini akan diperoleh dari kegiatan wawancara mendalam (indepth-interview) dengan subyek penelitian ini yang berusaha melakukan interprestasi atau memberikan makna terhadap perilaku individu-individu komunitas Punk, dalam proses komunikasi antar anggotanya di saat mereka menyelesaikan masalah atau isu yang sedang terjadi demi menjaga keharmonisan antar anggota komunitas. Karena penelitian ini bersifat kualitatif, maka instrumen untuk melakukan wawancara adalah penelitian sendiri dengan menggunkan pedoman wawancara (interview guide) yang tidak terstruktur dan bersifat open-ended. Pertanyaan-pertanyaan yang sifatnya open-ended tersebut merupakan sarana yang paling efektif untuk memahami otentisitas pengalaman individu. Hasil wawancara ini direkam dengan audiotape, maupun hand phone dan dicatat sebagai transkip wawancara.

Disamping wawancara juga dilakukan studi kepustakaan yaitu pengumpulan data dan informasi yang berasal dari sumber tertulis seperti surat kabar, buku-buku, literatur, majalah, internet, dan sebagainya. (Sutopo, 2002: $35)$.

5. Validitas Data

Suatu alat ukur dikatakan valid apabila alat ukur tersebut mengukur apa yang ingin diukur (Singarimbun, 1989: 124). Memiliki ketepatan dalam pengukuran atau mampu menunjukan dengan tepat ukuran besar kecilnya gejala yang akan diukur. Setelah mendapatkan data yang cukup lengkap dan peneliti mulai menyusun laporan, maka unit-unit laporan yang telah disusun dikonfirmasikan kepada key informant dengan tujuan menyesuaikan data/informasi yang didapat sesuai dengan kondisi riil di lapangan.
Analisa terhadap penelitan ini akan mengacu pada metode penelitan deskriptif yang dikemukakan oleh Noeng Muhajir (1996: 102). Langkahlangkah analisis data serta pengambilan kesimpulan dalam penelitian ini meliputi:

a. Menggambarkan fokus
penelitian dengan cara memformulasikan pertanyaan dengan cara tertentu yang dipahami oleh orang awam. Sehubungan dengan penelitian dalam masalah ini, secara operasional pertanyaan dalam penelitian ini adalah mengenai hal-hal yang berkaitan dengan perilaku individu komunitas Punk dalam proses komunikasi antar anggotanya, di saat mereka menyelesaikan masalah atau issu yang sedang terjadi demi menjaga keharmonisan antar anggota komunitas.

b. Meringkas data kontak langsung dengan individu, kejadian dan situasi penelitian.

c. Mengembangkan secara berkesinambungan pertanyaan analitik. Selama dilapangan peneliti bertanya, mencari jawaban dengan wawancara dan menganalisanya, dan kemudian mengembangkan pertanyaan-pertanyaan baru dan seterusnya hingga mendapatkan apa yang diharapkan.

d. Membuat catatan deskriptif untuk menyajikan data yang didapat. Langkah ini ditujukan dengan cara peneliti mulai menyusun narasi deskriptif yang didasarkan pada subyek peneliti yang merupakan anggota komunitas. Narasi ini dibuat dengan bersumber pada hasil wawancara dengan subyek yang memberikan pertanyaan atau pendapat mengenai halhal yang berkaitan dengan bagaimana pola komunikasi dalam penyelesaian masalah yang dilakukan oleh anggota dalam komunitas Punk di Kota Semarang.

6. Analisis data 
e. Melakukan analisa berdasarkan hasil wawancara yang telah disusun dalam bentuk narasi deskriptif sehingga dapat diungkap relevansi teori-teori yang digunakan untuk mengkaji keterbukaan dalam proses komunikasi antar anggota komunitas, di saat mereka menyelesaikan masalah atau issu yang sedang terjadi demi menjaga keharmonisan antar anggotanya.

\section{Jadwal penelitian}

Kegiatan penelitian yang akan dilakukan ini menggunakan prosedur sebagai berikut:

1. Persiapan

- Menyusun protokol penelitian

- Pengembangan pedoman penyusunan data

- Penyusunan jadwal kegiatan secara rinci

2. Pengumpulan data

- Pengumpulan data primer dan sekunder

- Melakukan review dan pembahasan data yang telah terkumpul dengan melakukan refleksinya. Menentukan strategi pengumpulan data yang dipandang tepat, serta menentukan fokus, serta pendalaman dan pemantapan pada pengumplan data berikutnya.

3. Analisis data

- Melakukan analisis dari data yang sudah terkumpul.

- Melakukan penarikan kesimpulan sebagai temuan penelitian, sekaligus menggunakannya sebagai saran dalam laporan akhir penelitian.

4. Penyusunan laporan penelitian

- Menyusun laporan awal

- Review laporan dilakukan dengan dosen pembimbing untuk mendiskusikan laporan yang telah disusun sementara.

- Perbaikan laporan, dan disusun sebagai laporan akhir penelitian

- Perbanyakan laporan sesuai kebutuhan

5. Waktu yang ditentukan

- Persiapan : 2 minggu

- Pengumpulan data :2 minggu

- Analisis Data : 1 bulan

- Penyusunan laporan: 1 bulan

Penelitian ini akan memerlukan waktu 3 bulan dan dilakukan mulai bulan Oktober 2011 hingga selesai bulan November 2011.

\section{PEMBAHASAN}

1. Sejarah Punk

Pada awal kemunculannya, Punk merupakan sebuah gerakan perlawanan yang dilakukan oleh sekelompok buruh di London, Inggris yang tidak puas dengan sistem sosial yang berlaku pada saat itu yang mengelompokkan masyarakat menjadi dua golongan, yaitu kaum pengusaha (pemilik modal) dan kaum pekerja. Ketidakpuasan para buruh terutama diakibatkan oleh perlakuan masyarakat kelas pengusaha terhadap kelas pekerja. Kesenjangan sosial yang terjadi dan eksploitasi yang dilakukan kaum pengusaha terhadap kaum buruh menimbulkan perasaan senasib diantara para buruh dan kemudian melahirkan sebuah pergerakan yang menentang sistem kapitalisme. Sejak tahun 1980-an, saat Punk merajalela di Amerika, golongan punk dan skinhead seolah-olah menyatu, karena mempunyai semangat yang sama. Namun, Punk juga dapat berarti jenis musik atau genre yang lahir di awal tahun1970-an. Punk juga bisa berarti ideologi hidup yang mencakup aspek sosial dan politik.

Pergerakan tersebut kemudian membentuk sebuah komunitas yang 
anggotanya terdiri atas kaum buruh yang mempunyai pandangan yang sama terhadap tindakan sewenang-wenang para pemilik modal. Dengan menganut prinsip Do It Yourself dan Equality, gerakan resistensi radikal yang kemudian menjadi budaya penentang tersebut dikenal sebagai Punk (www.punkpages.cjb.net / 10 Mei 2011 23.00 WIB).

2. Pengaruh dan Perkembangan Punk di Indonesia

Pergerakan Punk di Indonesia telah masuk sejak tahun 1970-an tetapi baru benar-benar meledak pada tahun 1990-an. Hal ini disebabkan oleh ekspos media massa terhadap komunitas Punk yang baru terjadi pada pertengahan 1990-an dan kemudian mengubah pergerakan resistensi radikal menjadi sebuah budaya trend global dari kapitalisme.

Disebut demikian karena, sekarang anak-anak muda yang mengikuti pergerakan Punk hanya sebatas penampilan luarnya saja dan tidak tahu apapun mengenai Punk itu sendiri kecuali anarkisme yang sering identik dengan komunitas Punk. Padahal, anarki menurut Punk adalah anarki dalam cara berpikir dan bagaimana Punk bisa melakukan pemberontakan dengan cara sendiri.

Terkait dengan sejarah pergerakan Punk, anggota komunitas Punk menuangkan ideologi pergerakan mereka melalui simbol-simbol yang sampai sekarang tetap melekat dan menjadi identitas dari komunitas Punk di seluruh pelosok wilayah. Simbolsimbol tersebut dituangkan melalui gaya hidup, cara berpakaian dan jenis musik yang dimainkan oleh anak-anak Punk.

Cara berpakaian anak-anak Punk yang cenderung lusuh dan terlihat menyeramkan karena berbagai macam aksesori yang tidak biasa digunakan oleh anak-anak muda pada umumnya mempunyai arti khusus dan berhubungan erat dengan sejarah awal pergerakan Punk.

Bukan karena keinginan untuk tampil beda dan untuk menarik perhatian saja. Simbol-simbol tersebut antara lain sepatu boots Doc Mart yang melambangkan kaum buruh itu sendiri sebagai penggagas pergerakan Punk, sedangkan celana jins ketat yang panjangnya di atas mata kaki dengan jas dan dasi yang sering dikenakan oleh para Rude Boy (komunitas Ska/Tutons) dimaksudkan untuk menyindir kaum Borjouis. Gaya rambut Mohawk, safety pin, kalung anjing dan gelang spike melambangkan perlawanan terhadap kemapanan dan modernisasi.

Komunitas Punk lahir di jalanan dan anggota dari komunitas tersebut juga merupakan orang-orang jalanan, maka tempat berkumpul anak-anak Punk adalah di jalan. Tempat yang biasa digunakan untuk berkumpul (dalam istilah komunitas Punk disebut sebagai nye-treet, diambil dari kata street yang berarti jalan) adalah di perempatan jalan dan sekitar pinggiran pusat keramaian, dimana mereka juga mencari uang dari mengamen.

3. Bentuk Komunikasi yang Terjadi di dalam Komunitas Punk.

Bentuk komunikasi yang terjadi di dalam komunitas Punk di Semarang bermacam-macam. Salah satunya ialah kegiatan nye-treet. Kegiatan tersebut sering dikenal dengan istilah 'Street Punk'. Dalam komunitas Punk terdapat individu-individu dengan berbagai macam jenis pola pemikiran idealisme Punk. Namun, inti dari pergerakan Punk itu sendiri apa pun cara pemikiran yang kita punya kita tetap sama yaitu 'Do It Yourself'. Idealisme tersebut seolah menjadi sebuah harga mati di dalam komunitas Punk. Dari idealisme 
tersebut, para anggota komunitas Punk mewujudkannya melalui fashion, life style dan terutama melalui musik.

Punk dan musik adalah satu kesatuan yang tidak dapat terpisahkan. Karena kebanyakan anak-anak Punk adalah musisi maka gerakan yang paling dominan adalah melalui musik, yaitu dengan mengusung komunitas musik indie label atau underground. Musik dengan irama ketukan tempo cepat dan suara gitar berdistorsi kasar serta syair lagu yang penuh dengan kritik sosial dan perlawanan terhadap sistem pemerintahan yang tidak adil merupakan ciri dari musik dalam komunitas Punk.

Selain itu, musik dengan syair-syair lagu yang sarat dengan kritik sosial politik dapat menjadi sarana pendidikan politik yang ampuh bagi anggota komunitas Punk. Tetapi, lirik lagu yang dimainkan oleh band-band Punk tidak hanya bertema sosial politik saja, ada juga yang mengangkat tema mengenai kehidupan sehari-hari anak-anak anggota komunitas Punk.

Bentuk media komunikasi yang ada di dalam komunitas Punk di Semarang adalah melalui newsletter, zine, forum bebas, gigs musik serta kegiatan nyetreet yang biasanya memakan waktu hingga berjam-jam dan dilakukan setiap hari terutama pada Sabtu malam.

Kegiatan nye-treet yang sering dilakukan oleh anak-anak Punk menjadi sarana paling efektif untuk berdiskusi, bertukar pikiran, bertukar pengalaman, dan saling bertukar informasi ataupun sebagai sarana sosialisasi pergerakan Punk untuk para Poser (orang yang tertarik dengan pergerakan Punk namun bukan seorang anggota komunitas Punk) dan juga sarana publikasi acara gigs musik yang akan diadakan oleh komunitas Punk di daerah tertentu.

Pada saat nye-treet tersebut, anakanak Punk biasanya berdiskusi seputar isu-isu yang terjadi di masyarakat maupun di dalam komunitasnya sendiri dan saling bertukar informasi berupa news letter, zine, kaset, literatur, majalah maupun pamflet acara musik terbitan underground. Pertukaran informasi yang terjadi tersebut biasanya menjadi sarana sosialisasi pergerakan Punk bagi anggota komunitas Punk yang baru bergabung dan ingin mengetahui lebih dalam mengenai Punk dan idealismenya. Berawal dari kegiatan nye-treet tersebut sering kali muncul diskusi mengenai penyelenggaraan event-event musik Punk.

Kegiatan-kegiatan seperti itulah yang memperkuat solidaritas dan menjadi media komunikasi bagi anggota komunitas Punk Kota Semarang khususnya yang berada di daerah Genuk. Namun, seiring dengan perkembangan jenis media serta kemajuan di bidang teknologi, anakanak dalam komunitas Punk tersebut saling berinteraksi dan berkomunikasi dengan anggota komunitas Punk di kota lainnya melalui internet.

4. Gambaran indikasi pola komunikasi yang terdapat di dalam komunitas Punk cah Genuk

Berikut ini merupakan paparan dari hasil penelitian setelah dilakukan wawancara dengan beberapa informan dalam studi deskriptif kualitatif ini. Diawali dari indikator deskripsi tentang gambaran umum pola komunikasi di dalam komunitas Punk ini mulai terbentuk, hingga sampai pada indikator tentang cara para anggota komunitas menjaga kohesivitas dan keharmonisan di dalam komunitas Punk itu sendiri. Penggambaran proses berfikir secara aktif untuk mengingat kembali pengalaman individu atas segala kejadian yang dialami di dalam komunitas selama sang informan tergabung di dalam komunitas Punk 
tersebut. Sehingga proses komunikasi antar individu maupun antar kelompok yang terjadi di dalam komunitas Punk seakan-akan dapat terlihat dari hasil wawancara mendalam (indepth interview) antara peneliti dengan kelima informan dari komunitas Punk cah Genuk tersebut. Pemilihan lima informan ini ditentukan berdasarkan kriteria sampel yang telah dijabarkan pada Bab sebelumnya, yang diharapkan mampu memberikan gambaran situasi dan kondisi secara komprehensif. Proses analisis data dalam penemuan ini, dimulai dengan mengkoordinasikan informan atau data dengan tujuan untuk mendapatkan waktu yang tepat didalam melakukan tahap wawancara, sehingga dalam proses wawancara setiap informan mampu mendeskripsikan pengalaman diri dengan total dan signifikan.

5. Pola Komunikasi yang dilakukan antara Anggota Komunitas Punk di Kota Semarang.

Dalam kehidupan sosial di masyarakat khususnya dalam komunitas Punk, terdapat individu-individu tertentu yang dengan mudahnya menjalin hubungan pertemanan setiap bertemu dengan teman yang baru. Bukan itu saja persahabatan mereka pun biasanya mampu bertahan dalam waktu yang lama. Sebaliknya, ada juga orangorang yang justru mengalami kesulitan dalam pergaulan. Banyak faktor yang menyebabkan keberhasilan dan kegagalan seseorang anggota komunitas dalam pergaulan, salah satunya adalah pola komunikasi mereka.

Tanpa kita sadari, sebenarnya pola komunikasi itu sendiri adalah berbagai kecenderungan dalam penyampaian isi pesan yang dikomunikasikan. Pada umumnya, seorang anggota komunitas dalam pergaulan tidak saja memahami dampak pola komunikasinya kepada orang lain, dia pun telah berhasil mengubahnya menjadi pola komunikasi yang luwes dan menyenangkan. Pola komunikasi tidak hanya mempengaruhi isi pesan yang akan disampaikan, bahkan dengan gaya penyampaian yang luwes akan menambah kekuatan bahkan melengkapi kekurangan isi pesan yang disampaikan.

Penelitian komunitas Punk ini, persahabatan diantara mereka terjalin karena mereka mempunyai kesamaan idealisme dan minat, yaitu genre musik Punk. Namun tidak hanya genre musik Punk saja yang dapat menyatukan mereka, adanya komunikasi yang efektif dan pemikiran yang sama di dalam tujuan komunitas juga merupakan faktor yang dapat mempererat persahabatan di antara anggota-anggota komunitas Punk.

Pola komunikasi setiap individu anggota komunitas Punk berbeda satu sama lain. Ada individu yang memiliki pola komunikasi yang fleksibel dan dapat menyesuaikan dengan kondisi individu di sekitarnya, sehingga dapat menciptakan suasana yang menyenangkan dan mampu membuat lawan bicaranya nyaman berlama-lama berkomunikasi dengannya. Namun, ada juga anggota yang memiliki pola komunikasi yang pasif, atau dengan kata lain dapat mempersulit komunikasi yang sedang berlangsung.

Pola komunikasi yang tidak sehat tersebut antara lain hanya berbicara sepenggal-penggal dan kurang respon terhadap masalah yang ada di sekelilingnya. Keterbatasan koordinasi antara kinerja otak dan indera pengucapan, membuat individu mengalami hambatan dalam berkomunikasi secara efektif. Hal ini seringkali tidak disadari oleh individu. Sepanjang pengetahuannya, ia sudah mengatakan semua yang ingin disampaikanya padahal belum semuanya tersampaikan. 
Ada juga anggota yang memiliki pola komunikasi tipe penyenang yaitu orang yang mempunyai satu tujuan dalam hidupnya, yaitu menyenangkan semua orang. Berbicara dengan tipe penyenang memang dapat menyenangkan, karena respon yang kita terima selalu memiliki kecenderungan positif, sehingga pola komunikasi seperti ini dapat mendangkalkan hubungan antar pribadi. Sulit sekali untuk mengetahui isi hati dari individu tipe penyenang karena ia tidak terbuka, ketidakterbukaannya itu justru cenderung membuatnya menumpuk semua perasaan dalam hati dan benaknya. Kalau tidak tertahankan, ia mudah menjadi orang yang depresi, tertekan, dan tidak bahagia, biasanya akan cenderung pendiam.

Uraian diatas mendiskripsikan bahwa pola komunikasi dapat melambangkan kepribadian seseorang anggota komunitas yang sesungguhnya, namun terdapat kemungkinan hal tersebut merupakan pola yang tengah dipelajari dan dikembangakan oleh komunitas tersebut. Dalam komunitas Punk, adakalanya untuk mendapatkan penerimaan dari para anggota lain, seorang anggota terpaksa mengikuti pola komunikasi anggota mayoritas komunitas yang tersebut, sehingga pola komunikasi tersebut dapat dipahami semua orang atau bersifat universal. Menurut peneliti, jika pola komunikasi anggota tersebut memang merupakan karakter suatu kepribadian sendiri, tentu saja tetap memerlukan koreksi, misalnya dengan meminta tanggapan orang lain di dalam komunitas.

Sehingga pola komunikasi yang dimiliki setiap anggota komunitas dapat menciptakan pola komunikasi yang sinergis dan efektif serta mampu menyelesaikan permasalahan di dalam komunitas sehingga dapat mempererat persahabatan diantara anggota-anggota komunitas Punk.

Apabila diaplikasikan secara benar komunikasi akan mencegah dan menghilangkan konflik antarpribadi, antarkelompok, antarsuku, antarbangsa, dan antarras. Hakikat komunikasi adalah proses penyampaian pesan dengan dengan menggunakan bahasa sebagai penyalurnya. Komunikasi berlangsung dalam berbagai tingkat kesengajaan untuk meraih tujuan dari komunikasi sendiri. Tujuan tersebut antara lain, mengubah sikap, opini, perilaku, dan mengubah masyarakat. Dimana dari tujuan tersebut dapat dilihat bahwa komunikasi tersebut memang berlangsung dari kesengajaan di mana fungsi dari komunikasi itu sendiri, menginformasikan, mendidik, menghibur, dan mempengaruhi (Marhaeni Fajar, 2009: 38).

$\begin{array}{crr}\text { Bateson dan } & \text { Watzlawick } \\ \text { mengemukakan } & \text { bahwa } & \text { hubungan } \\ \text { merupakan bagian dari sebuah sistem. }\end{array}$ Orang-orang dalam suatu hubungan selalu menciptakan seperangkat pengharapan, memperkuat hubungan yang lama, atau mengubah pola interaksi yang sudah ada (Littlejohn, 1996: 251).

6. Pemanfaatan Media Komunikasi Punk di Kota Semarang oleh anggotanya, dalam rangka menjaga keharmonisan antar komunitas.

Dalam media komunitas terdapat peranan dari orang lain yang mempengaruhi pola pikir kita, dan itu berada di dalam kelompok dimana kita juga menjadi anggotanya, besar atau kecil, formal atau informal. Kelompok orang ini bisa mempunyai dampak yang besar pada cara kita menerima pesan. Keanggotaan kelompok dapat menciptakan sikap prasangka yang sulit diubah. Berikut ini adalah jenis-jenis kelompok yang paling penting. 
Kelompok Primer (primary group) adalah sebuah kelompok (dua orang atau lebih) yang melibatkan perkumpulan yang anggotanya bertemu langsung dengan akrab selama jangka waktu yang lama. Kelompok Acuan (refference group) adalah sebuah kelompok yang dikenali dan digunakan sebagai standar acuan namun tidak mesti dimiliki. Kelompok Kasual (casual group) adalah sekelompok orang yang terbentuk satu kali saja dan anggota kelompok tersebut tidak saling mengenali satu sama lainya sebelum mereka berkumpul. (Severin, 1990: 219-220).

Komunitas Punk memiliki media yang biasa mereka gunakan untuk berkomunikasi antara anggota satu dengan yang lain baik itu dalam satu komunitas maupun dengan komunitas dari tempat yang berbeda pula. Mereka biasanya menggunakan media informasi berupa news letter, zine, forum bebas, kaset, literatur, majalah, maupun pamflet acara musik Gigs terbitan komunitas. Dari beberapa media yang sering digunakan dalam komunitas Punk, salah satunya ialah Zine. Penggagas media Zine, adalah individuindividu yang memahami dan memiliki pengetahuan lebih terkait dengan suatu hal dan peka terhadap suatu masalah sosial yang terdapat di masyarakat, dan ingin mengembangkan komunitas, sehingga dengan sukarela membuat kemudian membagikan zine secara gratis.

Pertukaran informasi yang terjadi tersebut biasanya menjadi sarana sosialisasi pergerakan Punk bagi anggota komunitas Punk yang baru bergabung dan ingin mengetahui lebih dalam mengenai Punk dan idealismenya. Proses komunikasi tersebut, mereka mencakup penggunaan media yang lebih moderen seperti internet. Meskipun mereka banyak hidup di jalanan, mereka juga mempunyai akun Friendster, Facebook, MySpace, hingga Blog.. Menggunakan jejaring tersebut para anggota komunitas Punk dapat berkomunikasi dan berbagi pesan informasi atau saling menyapa dengan kawan-kawan mereka dari komunitas lain hingga keluar daerah bahkan luar pulau.

Media massa jelas terkait dengan kultur, karena melalui media massa itulah pekerja kreatif dapat menyalurkan kreativitasnya dengan tepat. Meski media punya potensi menyebarluaskan karya kreatif terbaik dari pikiran dan jiwa manusia, beberapa krirtikus mengatakan media sangat obsesif terhadap subjek-subjek trendi, yang kadang menggelikan. Para kritikus ini juga menemukan kesalahan serius dalam perhatian media terhadap kultur pop, karena kultur pop dianggap tidak mengandung isi yang signifikan. (Marshall Mc Luhan, 1998: 506).

Melalui media, seluruh anggota komunitas saling berdiskusi tentang sebuah permasalahan atau isu yang berkembang di dalam komunitas, demi menjaga kepaduan kelompok dimana individu-individu didalamnya bersifat heterogen, hal ini dilakukan dengan cara saling menjaga komunikasi antar anggota, memahami satu sama lain, mempererat hubungan antar pribadi dan menjaga kekompakan antar semua anggota di dalam komunitas, meskipun tiap-tiap individu anggota komunitas memiliki tujuan yang berbeda-beda dalam cara penyelesaian masalah, namun hal itu tampaknya tidak menjadi penghalang dalam rangka menjaga keharmonisan dan kesatuan komunitas Punk.

\section{KESIMPULAN}

Penelitian ini terinspirasi dari masalah dalam pemahaman pola 
komunikasi yang terjadi di dalam komunitas Punk di kota Semarang. Dengan judul, "Memahami Pola Komunikasi Kelompok antar Anggota Komunitas Punk di Kota Semarang", dan peneliti mengkajinya dengan menggunakan metode deskriptif kualitatif.

Pada dasarnya penelitian ini bertujuan untuk mendapatkan gambaran dari informan mengenai berbagai gejala dan pola komunikasi yang terjadi di dalam komunitas Punk di Kota Semarang. Penelitian ini juga bertujuan untuk mengetahui bagaimana proses penyampaian pesan dan informasi antar individu di dalam komunitas sekaligus informan dengan individu-individu lain di dalam komunitas bahkan luar komunitas untuk mendapatkan respon dan umpan balik yang sesuai dengan isi pesan yang disampaikan oleh informan atau komunikan.

Berdasarkan penelitian yang telah dilakukan, maka peneliti mendapatkan beberapa kesimpulan sebagai berikut:

a. Pola Komunikasi yang dilakukan antar Anggota Komunitas Punk di Kota Semarang diwarnai oleh pola komunikasi dari setiap individu anggota komunitas Punk berbeda satu sama lain. Ada individu yang memiliki pola komunikasi yang fleksibel sehingga dapat menyesuaikan dengan sifat dan kondisi individu di sekitarnya, sehingga dapat menciptakan suasana yang menyenangkan dan mampu membuat lawan bicaranya betah untuk melakukan komunikasi dengan individu tersebut. Ada juga anggota yang memiliki pola komunikasi yang pasif, individu yang memiliki sifat seperti ini dapat mempersulit komunikasi yang sedang berlangsung, dengan hanya berbicara sepenggal-penggal dan kurang merespon masalah yang ada di sekelilingnya. Ada juga anggota yang memiliki pola komunikasi tipe penyenang atau biasa disebut penggembira, yaitu individu yang mempunyai satu tujuan dalam hidupnya, yaitu menyenangkan semua orang. Melakukan komunikasi dengan tipe penyenang memang dapat menyenangkan, karena dia akan mengangguk-angguk saja dan selalu meng "iya" kan semua pesan informasi yang dia terima tanpa memberikan tanggapan lebih menjauh, jadi pola komunikasi seperti ini dapat mendangkalkan hubungan antar pribadi. Sulit untuk mengetahui isi hati dari individu tipe penyenang ini, karena dia tidak terbuka dalam berkomunikasi, ketidakterbukaan itu justru cenderung membuat individu tersebut memendam semua perasaan dalam hati dan pikirannya. Jika tidak tertahankan, ia mudah menjadi orang yang depresi, tertekan, dan tidak bahagia, biasanya akan cenderung pendiam. Dapat diketahui bahwa pola komunikasi melambangkan kepribadian seseorang anggota komunitas yang sesungguhnya, namun bisa juga hal tersebut merupakan pola yang sedang dipelajari. Dalam komunitas Punk untuk mendapatkan penerimaan dari anggota lain, seorang individu terpaksa mengikuti pola komunikasi anggota komunitas yang lain, sehingga pola komunikasi tersebut dapat dipahami semua orang atau bersifat universal. Jika pola komunikasi anggota tersebut memang merupakan suatu kepribadian sendiri, tentu saja tetap memerlukan koreksi, misalnya dengan meminta tanggapan orang lain di dalam komunitas. Sehingga pola komunikasi yang dimiliki setiap anggota komunitas dapat menciptakan komunikasi yang efektif dan mampu menyelesaikan permasalahan di dalam komunitas sehingga dapat mempererat persahabatan diantara anggota-anggota komunitas Punk. 
b. Pemanfaatan Media Komunikasi Punk di Kota Semarang oleh anggotanya, dalam rangka menjaga keharmonisan antar komunitas, dilakukan dengan menempuh kegiatan berkomunikasi dan menyampaikan pesan informasi kepada anggota lain, mayoritas para individu di dalam komunitas Punk menggunakan sebuah media komunitas mereka yang biasa disebut Zine., Zine adalah sebuah media yang tidak untuk dikomersilkan, dan hanya dikonsumsi atau digunakan oleh komunitas underground, isinya mengutamakan tentang berbagai permasalahan komunitas, kritik terhadap pemerintahan yang memihak kepentingan sendiri yang tidak memperdulikan nasib rakyat jelata, maupun isu sosial yang terjadi di dalam masyarakat. Zine juga merupakan sebuah media perlawanan terhadap sistem hukum dan pemerintahan yang memihak terhadap kalangan atas. Penggagas Zine adalah para individu di dalam komunitas Punk yang memahami dan memiliki pengetahuan tentang hal tertentu dan peka terhadap permasalahan sosial yang terjadi di masyarakat, dan ingin mengembangkan komunitas Punk agar dapat dikenal oleh masyarakat luas dan juga masyarakat dapat mengetahui apa arti sebenarnya Punk itu. Pelaksanaan beragam tujuan tersebut maka, dengan sukarela beberapa individu di dalam komunitas Punk membuat dan kemudian membagikan zine secara gratis saat sedang ada acara Gigs berlangsung. Dalam proses komunikasi tersebut, mereka juga menggunakan media yang lebih moderen seperti internet. Meskipun mereka mempunyai media komunitas sendiri dan banyak hidup di jalanan, banyak dari anggota komunitas juga mempunyai akun jejaring Friendster, Facebook, MySpace, bahkan hingga Blog.. Dengan menggunakan jejaring tersebut para anggota komunitas Punk dapat berkomunikasi dan berbagi pesan informasi atau saling menyapa dengan kawan-kawan mereka dari komunitas lain hingga keluar kota, dalam rangka menjaga silaturahmi, mempererat tali persaudaraan, dan kedekatan meskipun telah lama mereka tidak bertemu.

\section{IMPLIKASI}

\section{Teoritis}

Penelitian ini memberikan implikasi teoritis bahwa kajian terhadap Pola Komunikasi yang Dilakukan antara Anggota Komunitas Punk di Kota Semarang. hubungan antar teori fungsional, media komunitas, dan teori pemikiranlah yang menjadi acuan dasar peneliti dalam melakukan penelitian di dalam komunitas ini. Berawal dari teori fungsional yang mengacu pada bagaimana para anggota komunitas mengungkapkan kesulitan dalam menghadapi sebuah permasalahn atau isu, bagaimana menjelaskan kronologi permasalahan, dan bagaimana para anggota komunitas menganalisis permasalahan yang sedang dihadapi hingga menemukan solusi. Dan dalam menyampaikan permasalahan yang terjadi kepada individu lain di dalam komunitas.

2. Metodologis

Implikasi metodologis penelitian ini adalah bersifat deskriptif dengan menggunakan metode kualitatif dengan perspektif interpretive. Metode ini digunakan untuk mencari data melalui interprestasi dari informasi yang didapat dari para informan untuk mengkaji pola komunikasi dan pemanfaatan media yang dilakukan oleh anggota komunitas Punk di Kota Semarang.

3. Praktis 
Digunakan sebagai masukan bagi peneliti-peneliti di waktu mendatang tentang bagaimana memahami pola komunikasi yang terjadi di dalam komunitas Punk, dan kepada khalayak luas agar dapat lebih mengenal apa itu sebuah komunitas Punk. Dengan penyajian yang bersifat universal sehingga dapat dengan mudah diterima oleh khalayak luas. Peneliti berharap semoga penelitian ini dapat memberikan kontribusi dan menyumbangkan cara-cara memahami dan mendeskripsikan berbagai pola pemanfaatan media komunikasi untuk menjaga keharmonisan diantara anggota komunitas Punk di kota Semarang ini.

Untuk komunitas Punk diharapkan mampu menjadikan pembelajaran dalam hal yang berhubungan dengan kehidupan berkomunikasi mereka, agar mampu menelaah sisi positif dalam pola komunikasi dan merubah sisi negatifnya sehingga pola komunikasi di dalam komunitas Punk menjadi lebih efisien dan bermanfaat.

\section{DAFTAR PUSTAKA}

Devito, Joseph A. 1997. Komunikasi Antarmanusia. Edisi 5. Jakarta: Professional Books.

Littlejohn, Stephen. W. 1992. Theories of Human Communication. (Edisi 2). New Mexcico: Wadsworth Publishing Company Albuquerque.

Littlejohn, Stephen. W. 1996. Theories of Human Communication. Sixth Edition. USA: Wadsworth Publishing Company.

Marhaeni, Fajar. 2009. Ilmu Komunikasi: Teori dan Praktik. Yogyakarta: Graha Ilmu.
McQuail, Dennis. 1987. Teori Komunikasi Massa Suatu Pengantar. Jakarta: Erlangga

McQuail, Dennis. 1996. Teori Komunikasi Massa, Suatu Pengantar. Edisi kedua. Bandung: Erlangga.

http://anyerpanarukan.blogspot.com/2008/0 4/punk-sebuah-pergerakanyang-menjadi.html/ oleh Japro di Kamis, April 10, 2008. diunduh 10 mei $201123.00 \mathrm{WIB}$

http://deathlock.wordpress.com/2007/11 /26/kekuatan-opresif-kelompok mayoritas/ by Xaliber on Senin, 26 November 2007 • Permalink Posted in Social, Trash Tagged kajian sederhana, repost, revisi, sosial, sosiologi/ diunduh $10 \mathrm{Mei}$ 2011 pukul 23.30 WIB

http://rumahtulisan.blogspot.com/2004/0 5/musik-rambut-danpemberontakan.html./ Diposkan oleh yes.i.do di 8:55 AM / diunduh 10 Mei 2011 Pukul 24.15 WIB

http://hooliganpunk.wordpress.com/201 0/02/28/perkembangan-punk-diindonesia/ Oleh : Aep Maulana 2010/02/28 / diunduh 11 January 2012, 11:30:20 WIB 
